\title{
Komik Pengenalan Angka Untuk Anak Usia Dini Di Kota Metro
}

\author{
ISNAINI NUR AZIZAH
}

Institut Agama Islam Ma'arif NU (IAIMNU) Metro Lampung

Email: zezelullaby@gmail.com

\section{MUHAMMAD YUSUF}

Institut Agama Islam Ma'arif NU (IAIMNU) Metro Lampung

Email:yusufiaimnu@gmail.com

\section{LELI FERTILIANA DEA}

Institut Agama Islam Ma'arif NU (IAIMNU) Metro Lampung

Email: leli.f.dea@gmail.com

Article received: 5 Maret 2020, Review process: 29 Mei 2020,

Article Accepted: 22 Maret 2021, Article published: 30 Maret 2021

\begin{abstract}
This research aims to create educational product of comics. This product make media to introduce numbers for early childhood. The subjects in this study were students for early childhood. They are TK Ma'arif 1 at 16c Metro South, TK Ma'arif 2 at 21 East Metro and RA Ma'arif 1 at 28 Purwosari Metro Utara. The development model used is the 4D development model, Thiagarajan which consists of 4 stages, define, design, develop and disseminate. The results of the material expert validation with a score of 3.60 with a very valid category. The results of design validation with a score of 3.43 with a very valid category. The results of the field test as much as $86 \%$ reached the indicator that the child could show / pronounce the names of numbers verbally and in writing, as many as $77 \%$ of the children reached the indicator which was able to write and mention the names of the numbers in order and consistently, as many as $69 \%$ of the children reached the indicator that was able to understand correspondence (for example "five" represents five things), as many as $80 \%$ of children reach the indicator that is able to understand the concept more and less
\end{abstract}

Keywords: Comics, Introduction To Numbers, Early Childhood

\begin{abstract}
Abstrak
Penelitian ini bertujuan untuk menghasilkan produk berupa komik edukatif sebagai media untuk mengenalkan angka kepada anak usia dini. Subjek penelitian ini adalah peserta didik sekolah mitra yaitu TK Ma'arif 1 di 16c Metro Selatan, TK Ma'arif 2 di 21 Metro Timur dan RA Ma'arif 1 di 28 Purwosari Metro Utara. Model pengembangan yang digunakan adalah model pengembangan 4D, Thiagarajan yang terdiri atas 4 tahap yaitu pendefinisian (define), perancangan (design), pengembangan (develop) dan penyebaran (desseminate). Hasil validasi ahli materi dengan skor sebesar 3,60 dengan kategori sangat valid. Hasil validasi desain dengan skor 3,43 dengan kategori sangat valid. Hasil uji lapangan sebanyak $86 \%$ mencapai indicator yaitu anak dapat menunjukkan / menyembutkan nama angka secara lisan dan tulisan, sebanyak $77 \%$
\end{abstract}


anak mencapai indikator yaitu dapat menulis dan menyebutkan nama angka secara urut dan konsisten, sebesar $69 \%$ anak mencapai indicator yaitu dapat memahami korespondensi 1 per 1 (misal "lima" mewakili lima benda), sebanyak $80 \%$ anak mencapai indicator yaitu dapat memahami konsep lebih banyak dan lebih sedikit

Kata Kunci: Komik, Pengenalan Angka, Anak Usia Dini

\section{PENDAHULUAN}

Anak Usia Dini (AUD) merupakan kelompok anak pada usia perkembangan yang unik. (Ariyanti, 2016) dikatakan unik karena proses tumbuh kembang anak terjadi pada masa golden age (masa emas) yang hanya terjadi satu kali dalam perkembangan kehidupan manusia. (Priyanto, 2015)(Trenggonowati \& Kulsum, 2018) (Pebriana, 2017)(Yusuf, 2017)(Yusuf, 2016). Akan tetapi proses dan hasilnya tidak dapat disamaratakan selayaknya proses belajar pada orang dewasa pada umumnya, karena anak-anak memiliki cara belajar yang berbeda dengan orang dewasa. (Dini \& 2016, n.d.) Oleh karena itu mengoptimalkan tumbuh kembang anak pada usia ini adalah cara yang paling tepat.

Peraturan kementrian pendidikan dan kebudayaan (Kemendikbud) menyatakan bahwa seleksi calon peserta didik baru kelas 1 Sekolah Dasar (SD) tidak diperbolehkan melakukan tes membaca, menulis dan berhitung (calistung). (Asiah, 2018) (Istiyani, 2014) Lembaga pendidikan sekolah dasar wajib menerima calon peserta didik baru kelas 1 tanpa melalui tes masuk sekolah dasar, seleksi yang dilakukan hanyalah untuk mempreoritaskan peserta didik berusia 6-7 tahun. (Mariyati, 2019) Kenyataannya, Instrumen seleksi masuk sekolah dasar nampaknya harus dikaji kembali. Banyak SD yang menyelenggarakan tes calistung walaupun tidak secara nyata ditulis pada pengumuman persyaratan seleksi penerimaan peserta didik baru. (Pratiwi, 2015) (Izzaty et al., 2017) Hal tersebut menjadikan orang tua khawatir jika anaknya yang belum menguasai calistung nantinya tidak diterima di sekolah yang diinginkan.

Syarat berupa tes calistung yang menjadi ketentuan masuk SD berdampak pada animo orang tua yang ingin meningkatkan kompetensi anak dengan mengikutsertakan les calistung pada anak di bawah 5 tahun. Hasil survey Widyawati kepada 68 ibu yang memiliki anak usia 4-6 tahun memperlihatkan bahwa 44\% ibu memberikan les kepada anaknya, dimana sebanyak $50 \%$ memberikan les calistung kepada anak mereka. (Ferly, 2016) Hal tersebut yang memicu banyak lembagalembaga penyelenggara PAUD menambahkan pada kurikulum mereka pembelajaran calistung. Tidak hanya itu, menjamurnya lembaga les privat calistung bagi anak usia dini sudah menjadi fenomena yang tidak asing lagi.

Faktanya, Terdapat perbedaan yang signifikan kematangan sekolah antara anak-anak yang mengikuti dan tidak mengikuti les calistung pada usia dini. Anak yang menerima calistung dini menampilkan prestasi belajar yang lebih rendah dibandingkan anak yang tidak mengenyam calistung dini. (Anita \& dkk, 2019) Bahkan anak yang tidak mengikuti les calistung memiliki skor konsentrasi dan mean skor lebih tinggi pada subtes penyesuaian sosial dan kemampuan kerja. Kelelahan akibat padatnya aktivitas akademik dan sedikitnya waktu bermain menjadi salah satu faktor penyebab rendahnya konsentasi dan kemampuan dalam penyesuaian sosial dan kemampuan kerja. (Ferly, 2016) 
Berhitung adalah salah satu pokok bahasan matematika yang diperlukan dalam kehidupan. (Nirawati \& Yetti, 2019) Peraturan Kementrian dan Pendidikan Nasional Nomor 58 Tahun 2009, menyatakan bahwa anak usia 5-6 tahun sudah mampu mengetahui konsep banyak sedikit, membilang banyak benda 1-10, mampu mengenal konsep bilangan, mengenal lambang bilangan, dan mengenal lambang huruf. (Reswita \& Wahyuni, 2018)

Mengenalkan konsep bilangan kepada anak usia dini tentunya memerlukan pembelajaran yang menyenangkan agar anak dapat tertarik untuk mengerjakannya. Semboyan yang tepat untuk menggambarkan keadaan ini adalah bahwa untuk anak usia dini "belajar adalah bermain dan bermain sambil belajar". (Ade Holis, 2016) Ramaini berhasil mengenalkan konsep bilangan pada anak usia dini melalui tabung pintar. (Remaini, 2019) Untuk menciptakan suasana bermain sambil belajar yang menyenangkan diperlukannya suatu media sebagai alat perantara.

Banyak orang tua yang menganggap gadget sebagai media pembelajaran yang efektif untuk memberikan edukasi kepada anak. (Z. D. Rahmawati, 2020) Selain itu, beberapa orang tua juga banyak yang menggunakan gadget sebagai pengasuh bagi anaknya. (Puji Asmaul Chusna, 2017) Survey penggunaan gadget seperti smartphone/tablet oleh anak-anak yang dilakukan The Asian Parent hasilnya cukup mengejutkan. Sebanyak $98 \%$ dari total 2500 sampel orang tua di Singapura, Thailand, Indonesia, Malaysia dan Filipina mengakui telah memperbolehkan anaknya menggunakan gadget. $14 \%$ dari anak-anak tersebut telah memiliki gadget sendiri. 33\% anak usia 3-5 tahun membutuhkan lebih dari 1 jam sekali duduk untuk bermain gadget. Alasan terbesar orang tua memperbolehkan anaknya menggunakan gandet adalah edukasi. Kenyataannya berbanding terbalik dengan harapan orang tua. (Insight, 2014)

Gadget hanya salah satu sarana untuk mengedukasi anak, bukan satu-satunya. Edukasi dapat dilakukan dengan hal lain yang lebih ramah terhadap kesehatan anak. Alternatif lain yang dapat dilakukan adalah dengan mendampingi anak-anak sembari memberikan edukasi. Journal of Clinical Child and Adolescent Psychology melaporkan hasil studinya tentang membaca bersama anak, bahwa interaksi anak dan ayah mendukung perilaku positif dan mereduksi risiko perilaku bermasalah anak, manfaat lainnya adalah melatih konsistensi dalam menjalani rutinitas bersama anak, menghabiskan waktu bersama anak, dan melakukan hal yang memberikan pilihan bagi anak.(Cohen et al., 2013) Membaca bersama anak dapat juga dilakukan bersama anak dibawah 5 tahun. Di sini anak ditantang untuk membangun imajinasi dari setiap kata yang ada. Orang tua dapat mengajak anak membaca buku cerita bergambar yang menarik seperti komik edukatif.

Komik memiliki banyak persamaan dengan gadget. Komik dapat dirancang dengan cerita yang dilengkapi gambar berwarna dan menarik. (Hidayah \& Ulva, 2017) (Nugraheni, 2017) (Subroto et al., 2020) Cerita dalam komik dapat dibacakan oleh orang tua ataupun saudara untuk memberikan waktu anak berinteraksi. Kita juga dapat melatih anak untuk menceritakan kembali komik tersebut. Bahkan tanpa membaca anak sudah dapat memahami cerita lewat gambar yang disajikan. Kelebihan komik selain dinikmati gambarnya sebagai hiburan juga dapat menginterprestasikan dan penilaian dalam kehidupan.

Juanda merancang komik bertemakan fabel untuk pembentukan karakter pada anak.(Juanda et al., 2015) Juniarti membuat Komik Why? World Customs yang dijadikan sebagai media pembelajaran anak usia dini. (Juniarti \& Teguh, 2016) 
Konsep penyajian yang digambarkan dalam komik tersebut dapat sebagai referensi pendidikan karakter pada anak usia dini. Rahmawati merancang media pembelajaran komik sebagai inovasi pembelajaran ketrampilan membaca berbasis pendidikan karakter. (I. Y. Rahmawati, 2017) Penggunaan komik sebagai media pembelajaran bagi anak sudah banyak diteliti. Akan tetapi penggunakan komik sebagai media untuk mengenalkan angka kepada anak usia dini masih belum ditemukan. Oleh karena itu pada penelitian ini penulis akan mengembangkan media komik untuk mengenalkan angka pada anak usia dini.

\section{METODOLOGI}

Penelitian dan pengembangan komik edukatif sebagai media pengenalan angka pada anak usia dini dilaksanakan di sekolah mitra. Ada 3 sekolah mitra yaitu TK Ma'arif 1 di 16c Metro Selatan, TK Ma'arif 2 di 21 Metro Timur dan RA Ma'arif 1 di 28 Purwosari Metro Utara. Jenis penelitian ini adalah Research \& Development (R\&D). R\&D adalah jenis penelitian untuk menghasilkan produk tertentu (Putra, 2011) (Hanafi, 2017), mengembangkan produk yang sudah ada dan menguji keefektifannya. (Purnama, 2016) Tujuan penelitian ini adalah menghasilkan produk pengembangan media pembelajaran matematika berupa komik edukatif untuk mengenalkan angka 110 kepada anak usia dini. Produk yang telah dirancang secara sistematis kemudian di uji lapangan, di evaluasi dan di revisi sampai memenuhi kriteria tertentu yaitu kualitas dan efektivitas.

Model pengembangan yang digunakan adalah model pengembangan 4D, Thiagarajan yang terdiri atas 4 tahap yaitu pendefinisian (define), perancangan (design), pengembangan (develop) dan penyebaran (desseminate).(Azizah, 2017) Prosedur pengembangan dapat dilihat pada bagan 1

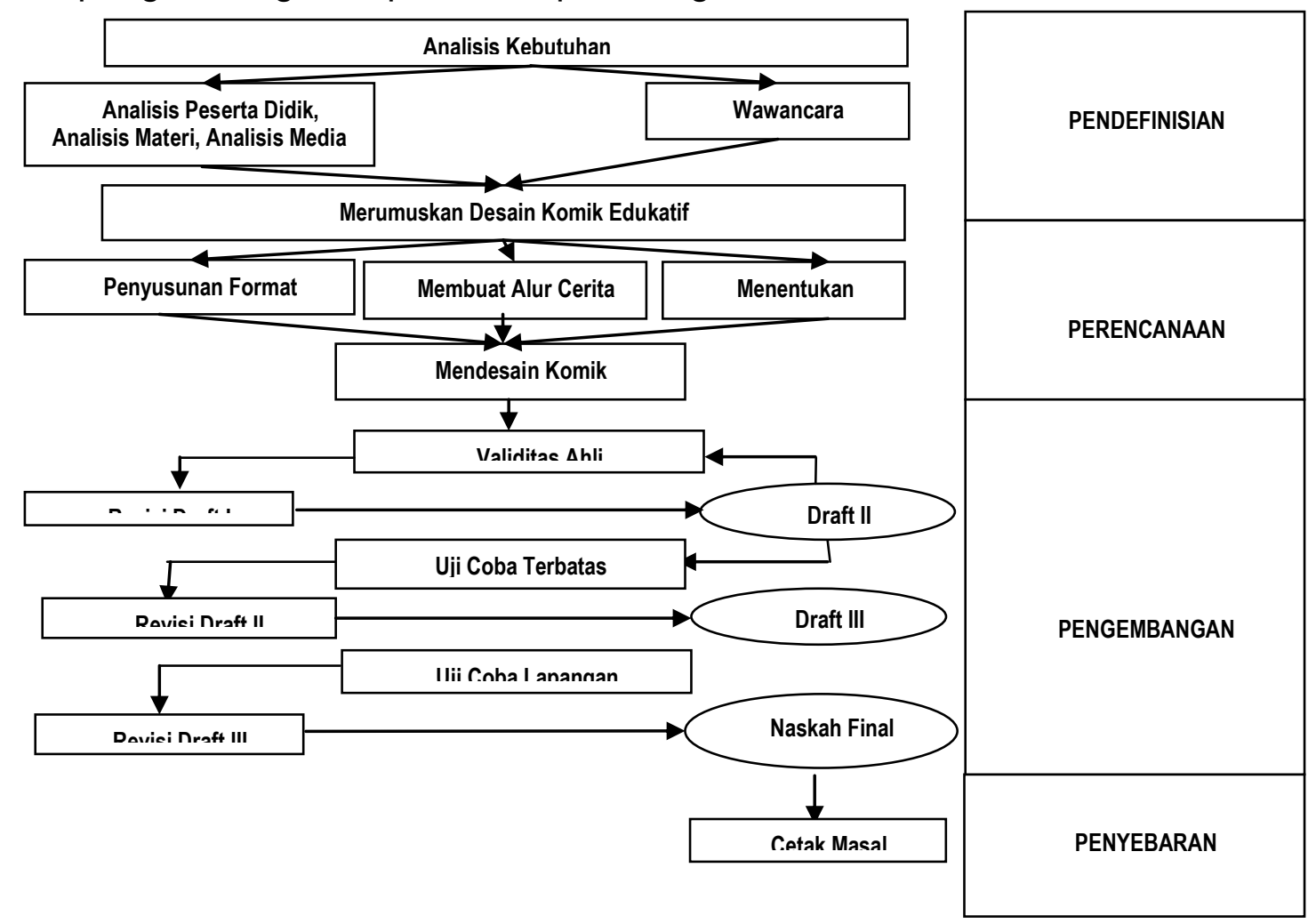

Bagan 1 Prosedur Pengembangan R\&D Thiagarajan 
Pada tahap (define) pendefinisian dilakukan analisis kebutuhan yang meliputi analisis peserta didik, analisis materi, analisis media dan wawancara kepada guru. Analisis peserta dilakukan untuk mengidentifikasi masalah dan mengetahui karakteristik peserta didik dalam hal ini adalah anak usia dini di sekolah mitra. Sekolah mitra adalah sekolah binaan dosen-dosen Pendidikan Islam Anak Usia Dini (PIAUD) IAIMNU Metro Lampung yang berkompeten di bidangnya. terdapat tiga sekolah diantaranya TK Ma'arif 1 di 16c Metro Selatan, TK Ma'arif 2 di 21 Metro Timur dan RA Ma'arif 1 di 28 Purwosari Metro Utara. Analisis materi yaitu materi pengenalan angka 1-10 untuk anak usia dini meliputi bagaimana cara menyampaikan, indikator dan batasan-batasan dalam mengenalkan angka pada anak usia dini. Analisis media dengan cara mengidentifikasi kelebihan dan kekurangan media yang sudah pernah digunakan peserta didik. Selanjutnya data dikumpulkan dari buku, jurnal, baik dalam bentuk hard copy atau soft copy. Hasil dari tahap pendefinisian menjadi modal dalam merancang produk dan menyempurnakan media yang akan dikembangkan. Wawancara terhadap guru kelas dilakukan untuk mengetahui masalah yang terjadi dilapangan seperti ketersediaan media pembelajaran dan proses pembelajaran yang dilakukan di sekolah mitra.

Tahap (design) perancangan, pada tahap ini peneliti merancang produk dengan menyusun unsur-unsur yang akan dituangkan pada produk. Langkah awal yang dilakukan adalah menentukan alur cerita, tokoh dan karakter tokoh pada komik. Alur cerita diselaraskan dengan materi dan konflik yang biasa terjadi pada kehidupan peserta didik TK mitra. Selanjutnya, peneliti membuat sketsa gambar secara manual menggunakan pensil dan kertas kemudian sketsa di scan dan di gambar ulang menggunakan aplikasi. Peniliti menggunakan dua aplikasi utama dalam menyusun produk yaitu Coreldraw dan Manga Studio 5. Tahap (develop) pengembangan, pada tahap ini dilakukan uji terhadap produk awal komik edukatif (draf 1). Uji coba dilakukan beberapa tahap diantaranya uji ahli, uji terbatas dan uji lapangan. Ahli yang menguji produk sebanyak 2 ahli terdiri atas ahli materi dan ahli media. Ahli materi adalah Leli Fertiliana Dea, M.Pd ketua program studi PIAUD IAIMNU Metro Lampung sekaligus pembina sekolah mitra. Ahli media Restilawati Woe Titi cahyani, M.Pd adalah dosen Institut Agama Islam Negeri (IAIN) Jurai Siwo Metro. Ahli media merupakan penulis komik matematika Aira pada materi Sistem Persamaan Linier Dua Variabel (SPLDV). Berdasarkan masukan dan hasil uji ahli, selanjutnya produk divefisi dan diberi nama draf 2. Draf 2 kemudian diujicobakan kepada kelompok terbatas dalam hal ini adalah 6 peserta didik diluar sekolah mitra beserta wali murid sebagai observer. Berdasarkan hasil uji coba terbatas dilakukan revisi kembali dan diberi nama draf 3. Selanjutnya Draf 3 diujicobakan kembali pada uji lapangan yaitu peserta didik sekolah mitra sebagai subjek penelitian. Berdasarkan hasil uji lapangan dan angket yang diberikan kepada guru dan orang tua murid selanjutnya draf 3 direvisi terakhir menjadi draf 4 sebelum di cetak dalam skala besar. Tahap (desseminate) penyebaran, komik edukatif pengenalan angka 1-10 yang telah beberapa kali diujicobakan dan mengalami revisi yang berulang-ulang dirasa telah siap dan efektif untuk disebarkan sebagai bahan ajar alternatif di sekolah-sekolah mitra. Pada tahap ini komik edukatif di serahkan ke sekolah mitra masing-masing 25 eksemplar. 


\section{HASIL DAN PEMBAHASAN}

Untuk lebih mudah dalam membaca hasil penelitian akan kami sajikan sesuai urutan tahapan penelitian R\&D dengan model pengembangan 4D. Pada tahap define tahapan yang dilakukan adalah analisis kebutuhan meliputi analisis peserta didik, analisis materi, analisis media dan wawancara. Hasil dari analisis peserta didik terkait jumlah peserta didik di sekolah mitra. TK Ma'arif 1 sebanyak 31 anak, TK Ma'arif 2 sebanyak 57 anak dan RA Ma'arif 1 sebanyak 57 anak. peserta didik dikategorikan menjadi dua kelas yaitu kelas $A$ untuk peserta didik usia 4-5 tahun dan kelas $B$ untuk peserta didik usia 5-6 tahun. Karakteristik peserta didik pada umumnya sama, senang belajar sambil bermain, belajar menggunakan media ataupun alat peraga, belajar langsung praktek.

Hasil dari analisis materi yaitu rincian tema, subtema dan cakupan tema/subtema. Hasil analisis media berdasarkan wawancara dan observasi. Media yang digunakan untuk mengenalkan angka di sekolah diantaranya gambar/poster, kartu angka, pasir, tanah, menggunakan jari tangan, dan menjadikan benda di sekitar sebagai media dalam menghitung. Metode yang digunakan adalah bernyanyi dengan alat peraga, tanya jawab, menyambungkan titik-titik, dan mencari angka. Media yang sudah digunakan di sekolah tentunya memiliki kelebihan dan kekurangan. Diantara kelebihan media tersebut adalah media sudah siap untuk digunakan dan praktis. Kekurangan media tersebut adalah anak mudah jenuh. Peserta didik membutuhkan media yang menyenangkan dan tidak membosankan, menarik dan beragam.

Hasil penelitian tahap design. Berdasarkan hasil dari analisis kebutuhan, pada tahap design peneliti membuat rancangan komik edukatif yang akan dibuat. Tahaptahap dalam merancang komik diantaranya menyusun struktur komik, menentukan alur cerita, tokoh, dan tema yang akan digunakan dalam komik yang dikembangkan. Struktur komik diantaranya: cover. Berisi judul buku, penulis dan dilengkapi dengan gambar sebagai ilustrasi isi komik. Pengenalan tokoh: Tokoh utama pada komik ini adalah Fatkhi dan Fara, Fatkhi dan Fara merupakan sepasang kakak beradik. Fatkhi berumur 8 tahun merupakan siswa SD kelas 2 sedangkan Fara berusia 5 tahun. Tokoh pendukung yang sering berinteraksi dalam cerita adalah Ayah, Ibu, Kakek, dan Hilya teman Fara. Penyajian materi: materi pengenalan angka disajikan dengan menampilkan beberapa unsur yaitu judul materi, tema, sub tema, pengenalan konsep, pengembangan konsep, dan challenge (tantangan). Materi disajikan dalam bentuk cerita yang menggambarkan tema. Nomor halaman. Nomor halaman di sebelah kanan bawah berguna untuk memudahkan dalam mengingat halaman yang terakhir dibaca. Lirik lagu tentang angka. Ada beberapa lirik lagu yang disisipkan dalam komik diantaranya lagu berjudul dua mata saya pada ateri angka dua, satu-satu aku sayang ibu pada materi angka tida, balonku ada lima pada materi angka lima, dan bangun pagi pada materi angka delapan. Alur Cerita dirancang dan disesuaikan dengan tema dan sub tema hasil analisis materi pada tahap sebelumnya. Setelah cerita dirasakan telah cocok kemudian dilanjutkan dengan menggambar pola yang mengilustrasikan 
cerita. Gambar diusahakan sejelas mungkin sehingga peserta didik tidak perlu kesulitan membaca karena alur cerita dapat tersampaikan dengan melihat gambar.

Hasil penelitian tahap develop diantaranya: Uji Coba Ahli. Pada tahap ini telah dihasilkan rancangan komik draft 1 yang siap untuk di ujicobakan. Ujicoba pertama adalah uji ahli. Ahli terdiri dari ahli materi dan ahli media. Ahli materi yang dipilih adalah Leli Fertiliana Dea, M.Pd. Ahli materi adalah seorang yang ahli di bidang pendidikan anak usia dini. Ahli materi adalah salah satu pembina sekolah mitra sekaligus ketua prodi pendidikan anak usia dini (PIAUD) di IAIM NU Metro Lampung. Ahli media adalah Restilawati Woe Titi Cahyani. Ahli media adalah dosen di Institut Agama Islam Negeri (IAIN) Jurai Siwo Metro. Ahli media mrupakan penulis komik media pembelajaran matematika Aira materi Sistem Persamaan Linier Dua Variabel (SPLDV).

\section{Tabel 1 Kisi-Kisi Instrumen Validasi Materi}

\begin{tabular}{|c|l|c|}
\hline No & \multicolumn{1}{|c|}{ Indikator } & \multicolumn{1}{|c|}{ Item } \\
\hline 1 & $\begin{array}{l}\text { Kesesuaian komik dengan tahapan pengenalan angka } \\
\text { secara lisan pada AUD }\end{array}$ & $\mathrm{a}, \mathrm{b}, \mathrm{c}$ \\
\hline 2 & $\begin{array}{l}\text { Kesesuaian komik dengan tahapan pengenalan angka } \\
\text { secara tulisan pada AUD }\end{array}$ & $\mathrm{d}, \mathrm{e}, \mathrm{f}$ \\
\hline 3 & $\begin{array}{l}\text { Komik edukatif mencakup semua materi } \\
\mathrm{g}, \mathrm{h}, \mathrm{I}, \mathrm{j}, \mathrm{k}, \mathrm{I}, \\
\mathrm{m}, \mathrm{n}, \mathrm{o}, \mathrm{p}\end{array}$ \\
\hline 4 & $\begin{array}{l}\text { Kesesuaian alur cerita, gambar dan karakteristik peserta } \\
\text { didik }\end{array}$ & $\mathrm{q}, \mathrm{r}, \mathrm{s}, \mathrm{t}$ \\
\hline
\end{tabular}

Berdasarkan hasil uji ahli materi ada beberapa saran yang diberikan. Revisi yang dilakukan berdasarkan saran dari ahli materi diantaranya:

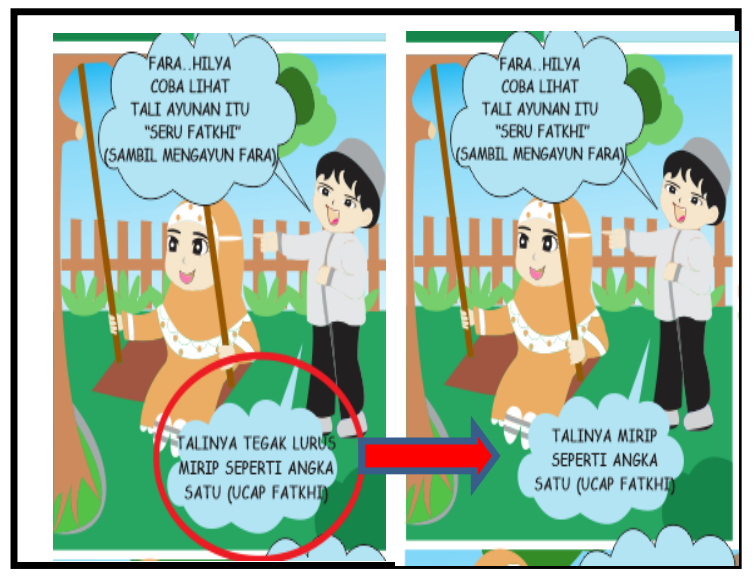

\section{Gambar 1 Contoh Revisi Bahasa}

Menurut ahli materi anak usia dini belum belajar tentang konsep tegak lurus sehingga menggunakan bahasa tegak lurus dianggap kurang sesuai dengan usia dini. Maka bahasa harus diganti dengan yang mudah dipahami. Revisi yang dilakukan 
adalah menghapus kata tegak lurus. Menyesuaikan konsep komik dengan konsep pengenalan angka yang diajarkan di PAUD

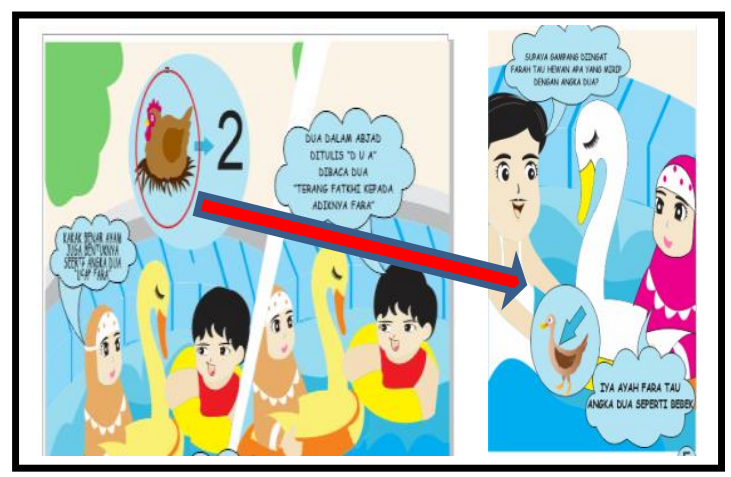

\section{Gambar 2 Contoh Revisi Penyesuaian Konsep}

Pada materi pengenalan angka dua penulis menggunakan ilustrasi ayam bertelur. Menurut ahli materi ilustrasi yang lebih tepat adalah bebek. Bebek adalah hewan yang biasa digunakan oleh guru sebagai contoh mengajarkan angka dua sehingga peserta didik lebih mudah memahami materi. Menambahkan lirik lagu yang berkaitan dengan materi

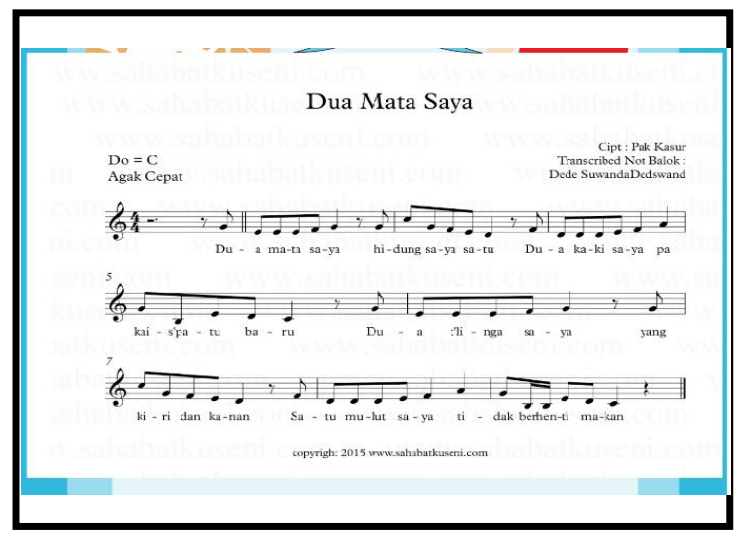

\section{Gambar 3 Contoh Revisi Penambahan Lirik Lagu}

Agar anak tidak bosan dengan materi maka diselingi dengan bernyanyi. Lagu yang dipilih disesuaikan dengan materi yaitu tentang angka. Bernyanyi adalah salah satu metode yang dapat digunakan dalam mengenalkan angka. Menggunakan ilustrasi gambar yang mudah dipahami.

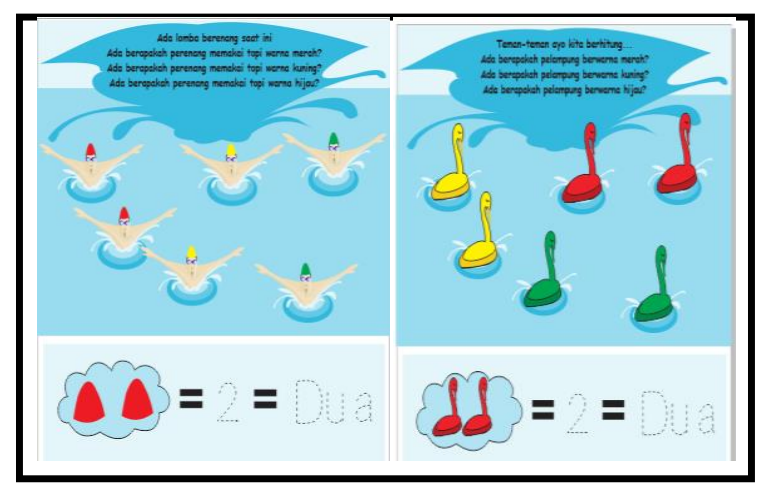

Gambar 4 Contoh Revisi ilustrasi Gambar Latihan 
Pada draft 1 penulis menggunakan "perenang" sebagai latihan dalam menghitung. Menurut ahli materi perenang dewasa kurang cocok untuk latihan anak usia dini. Saran yang diberikan adalah dengan menghitung angsa atau bebek sesuai materi yang telah di ajarkan sebelumnya.

Setelah dilakukan uji ahli. Ahli diberikan instrumen angket yang harus di isi. Angket adalah instrument yang digunakan dalam menilai kevalidan produk. Angket menggunakan skala likert dengan pilihan jawaban sebanyak 4 pilihan. Skor yang diperoleh dari uji ahli materi adalah 3,60. Skor tersebut berada pada kisaran nilai 3,254,00 sehingga dapat dikategorikan sangat valid.

Tabel 2 Kisi-Kisi Instrumen Validasi Media

\begin{tabular}{|l|l|l|}
\hline No & \multicolumn{1}{|c|}{ Indikator } & \multicolumn{1}{c|}{ Item } \\
\hline 1 & Desain Tampilan & $\mathrm{a}, \mathrm{b}, \mathrm{c}, \mathrm{d}, \mathrm{e}, \mathrm{f}, \mathrm{g}$ \\
\hline 2 & Kepraktisan Media & $\mathrm{h}, \mathrm{i}, \mathrm{j}$ \\
\hline 3 & Penggunaan Bahan & $\mathrm{k}, \mathrm{I}$ \\
\hline 4 & Keindahan Bentuk Media & $\mathrm{m}, \mathrm{n}$ \\
\hline
\end{tabular}

Berdasarkan hasil uji media ada beberapa saran yang diberikan. Revisi yang dilakukan berdasarkan saran dari ahli media diantaranya:

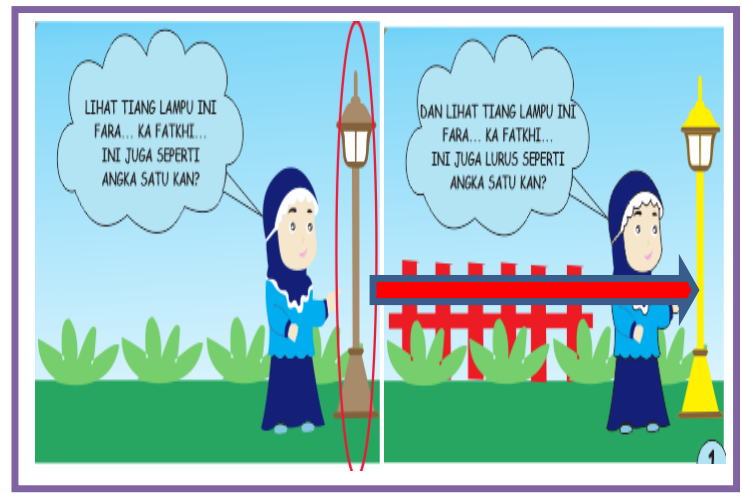

\section{Gambar 5 Contoh Revisi warna Objek Gambar}

Warna yang terang untuk objek yang diterangkan contohnya tiang lampung berguna agar anak lebih terfokus kepada objek sehingga materi yang ingin disampaikan dapat dipahami. Setelah dilakukan uji media, instrumen angket dinilai oleh ahli media kemudian dihitung skor kevalidan produk. Angket menggunakan skala likert dengan pilihan jawaban sebanyak 4 pilihan. Skor yang diperoleh dari uji media adalah 3,43. Skor tersebut berada pada kisaran nilai 3,25-4,00 sehingga dapat dikategorikan sangat valid.

Uji Terbatas. Setelah produk diuji ahli kemudian direvisi menjadi draft 2. Draf 2 kemudian diujicobakan kepada kelompok terbatas. Subjek kelompok terbatas terdiri atas 6 peserta didik di luar sekolah mitra beserta orang tua. Subjek uji terbatas berasal dari TK Khodijah 16c Mulyojati Metro Barat. Orang tua selain sebagai pendamping belajar peserta didik juga sebagai observer. Saran yang diberikan oleh orang tua 
peserta didik diantaranya: Mengganti warna dengan warna-warna yang disukai anakanak.

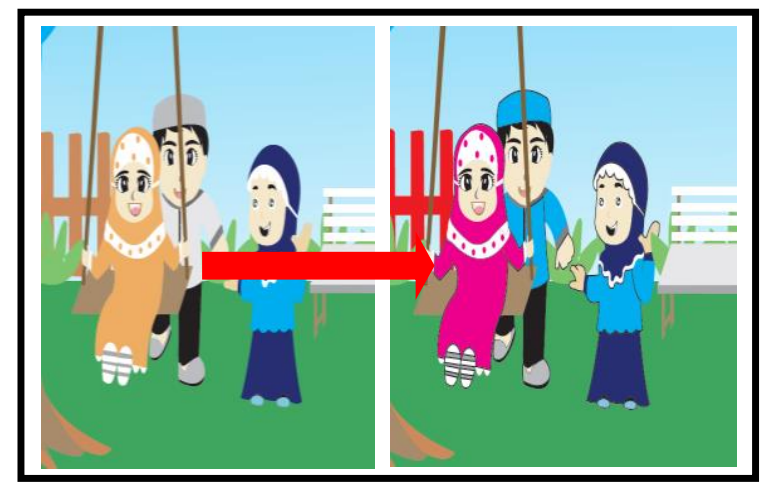

\section{Gambar 6 Contoh Revisi Hasil Uji Terbatas}

Berdasarkan hasil uji coba terbatas dilakukan revisi kembali dan diberi nama draft 3. Uji Lapangan. Setelah produk diuji terbatas kemudian produk direvisi menjadi draft 3. Selanjutnya Draf 3 diujicobakan kembali pada uji lapangan yaitu peserta didik sekolah mitra. Hasil uji coba lapangan sebanyak $86 \%$ mencapai indikator yaitu anak dapat menunjukkan / menyembutkan nama angka secara lisan dan tulisan, sebanyak $77 \%$ anak mencapai indikator yaitu dapat menulis dan menyebutkan nama angka secara urut dan konsisten, sebesar 69\% anak mencapai indikator yaitu dapat memahami korespondensi 1 per 1 (missal "lima" mewakili lima benda), sebanyak 80\% anak mencapai indikator yaitu dapat memahami konsep lebih banyak dan lebih sedikit. Hasil Penelitian tahap disseminate. Dokumentasi penyerahan komik kedukatif matematika pengenalan angka 1-10 untuk PAUD

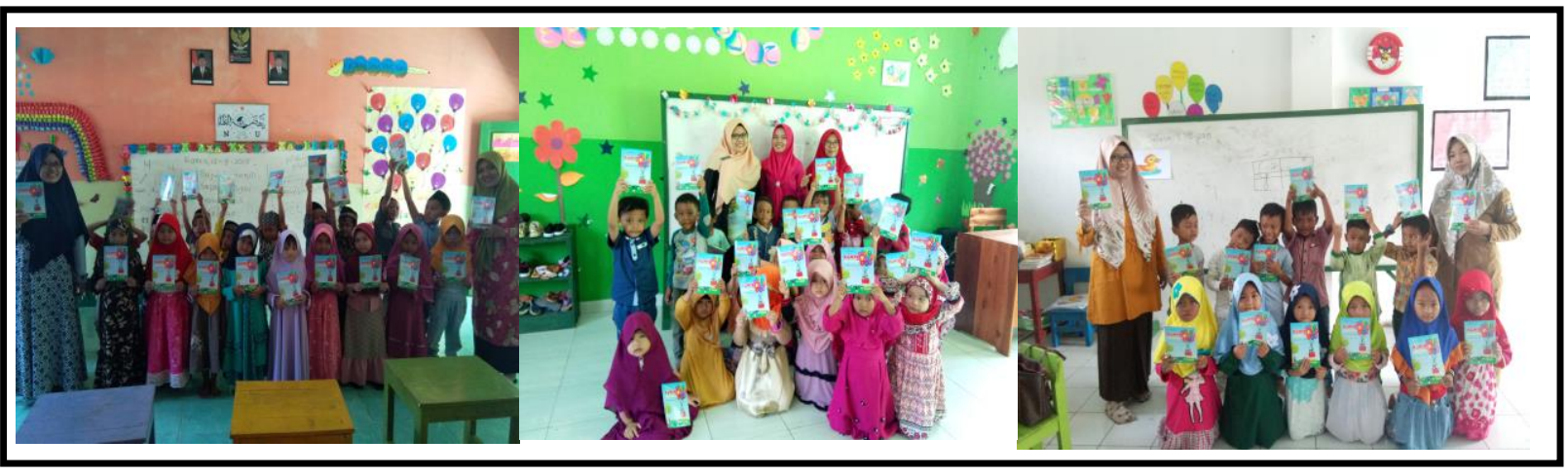

Gambar 7 Dokumentasi Penyerahan Komik di RA Ma'arif 1 Metro Utara

\section{PEMBAHASAN}

Hasil analis validasi materi dengan skor 3,60 termasuk kategori "sangat valid". Artinya validator menyatakan bahwa komik yang dikembangkan sangat sesuai dengan tahapan pengenalan angka secara lisan maupun tulisan dan komik telah mencakup semua materi yang diajarkan serta alur cerita dan gambar sangat sesuai dengan karakteristik peserta didik. konsep pengenalan angka menggunakan komik ini selaras dengan teori pola pattern yang menyatakan bahwa pengenalan angka kepada anak usia dini menarik dilakukan dengan cara menyusun serangkaian warna/benda/suara yang dapat diulang. (Lasuka et al., 2018). Berdasarkan penilaian validator materi 
dapat dipahami bahwa komik pengenalan angka yang telah dikembangkan layak untuk diujicobakan meskipun masih harus disempurnakan.

Hasil validasi media dengan skor 3,43 termasuk dalam kategori "sangat valid". Artinya desain tampilan komik sangat sesuai dengan anak usia dini baik alur cerita, warna dan gambar, media praktis digunakan dan sangat menarik. Media dapat membantu mengoptimalkan proses pembelajaran terutama materi pengenalan angka. Hal ini sejalan dengan (Zahriani Jf \& Sukiman, 2020) yang mengatakan bahwa pemanfaatan media pembelajaran diyakini dapat membantu mengoptimalkan kecerdasan naturalistic anak di kelas. Ahli media memberikan saran agar obyek yang dijelaskan diberikan warna kontras supaya peserta didik focus kepada benda yang sedang dibahas. Hal ini sejalan dengan pendapat (Khadijah, 2015) yang mengatakan bahwa kesesuaian warna mempertajam kualitas realistik objek dan memilihan warna yang tepat dengan karakteristik anak usia dini dapat mendorong semangat belajar anak. Sebab warna merupakan unsur visual yang sangat penting yang harus diperhatikan dalam menyusun media pembelajaran untuk anak.

Analisis efektifitas penggunaan media komik pengenalan angka berdasarkan hasil uji coba lapangan dapat disimpulkan bahwa komik pengenalan angka efektis sebagai media pengenalan angka untuk anak usia dini. Catatan positif selama penelitian berdasarkan tanggapan guru dan orang tua murid bahwa komik yang dihasilkan cocok digunakan untuk anak usia dini terutama usia 4-5 tahun baik digunakan sebagai media pembelajaran di sekolah maupun di rumah.

\section{SIMPULAN}

Berdasarkan hasil penelitian dapat disimpulkan bahwa komik edukatif efektif untuk digunakan sebagai media dalam mengenalkan angka 1-10 kepada anak usia dini. Komik edukatif juga dapat menjadi alternative permasalahan penggunaan gadget pada anak

Proses pembuatan komik edukatif sebagai media pengenalan angka 1-10 untuk anak usia dini di Kota Metro dilakukan dengan beberapa tahap. Tahap pertama merancang komik yang sesuai dengan kebutuhan peserta didik, materi dan kurikulum untuk anak usia dini. Selanjutnya, menentukan alur cerita penokohan dan unsur-unsur yang akan dituangkan dalam komik seperti: judul materi, latihan dan lagu. Komik di gambar menggunakan bantuan software correl draw. Komik yang telah di buat di uji cobakan sebanyak tiga kali yaitu uji ahli (ahli media dan ahli materi), uji terbatas dan uji lapangan. Naskah final adalah hasil revisi dari uji coba yang dilakuakan.

Berdasarkan hasil observasi lapangan sebanyak $86 \%$ mencapai indikator yaitu anak dapat menunjukkan / menyembutkan nama angka secara lisan dan tulisan, sebanyak $77 \%$ anak mencapai indikator yaitu dapat menulis dan menyebutkan nama angka secara urut dan konsisten, sebesar $69 \%$ anak mencapai indikator yaitu dapat memahami korespondensi 1 per 1 (missal "lima" mewakili lima benda), sebanyak 80\% anak mencapai indikator yaitu dapat memahami konsep lebih banyak dan lebih sedikit

\section{DAFTAR RUJUKAN}

Ade Holis. (2016). Belajar Melalui Bermain untuk Pengembangan Kreativitas dan Kognitif Anak Usia Dini. Jurnal Pendidikan Universitas Garut, 10(1), 23-37.

Anita, F., \& dkk. (2019). "Perbedaan Prestasi Belajar Anak Usia Sekolah Pada Pembelajaran Membaca, Menulis, Berhitung (Calistung) Dini di SD Katolik Hati Kudus Rajawali Makassar." Journal of Chemical Information and Modeling, 53(9). 
https://doi.org/10.1017/CBO9781107415324.004

Ariyanti, T. (2016). Pentingnya Pendidikan Anak Usia Dini Bagi Tumbuh Kembang Anak the Importance of Childhood Education for Child Development. Jurnal Dinamika Pendidikan Dasar, 8 NO 1, 50-58.

Asiah, N. (2018). Pembelajaran Calistung Pendidikan Anak Usia Dini Dan Ujian Masuk Calistung Sekolah Dasar Di Bandar Lampung. Terampil : Jurnal Pendidikan dan Pembelajaran Dasar, 5(1), 19. https://doi.org/10.24042/terampil.v5i1.2746

Azizah, I. N. (2017). Lembar Kerja Peserta Didik Materi Aritmatika Sosial dengan Model Pengembangan Thiagarajan. NUMERICAL: Jurnal Matematika dan Pendidikan Matematika, 1(2), 127-146. https://journal.iaimnumetrolampung.ac.id/index.php/numerical/article/view/132/138 Cohen, J. R., Hankin, B. L., Gibb, B. E., Hammen, C., Hazel, N. A., Ma, D., Yao, S., Zhu, X. Z., \& Abela, J. R. Z. (2013). Negative Attachment Cognitions and Emotional Distress in Mainland Chinese Adolescents: A Prospective Multiwave Test of Vulnerability-Stress and Stress Generation Models. Journal of Clinical Child and Adolescent Psychology, 42(4), 531-544. https://doi.org/10.1080/15374416.2012.749787

Dini, L. M.-: J. I. T. K. A. U., \& 2016, undefined. (n.d.). Tuntutan Calistung pada Anak Usia Dini. Ejournal.Uin-Suka.Ac.ld. http://ejournal.uinsuka.ac.id/tarbiyah/index.php/goldenage/article/view/1928

Ferly, I. R. (2016). Perbedaan Kematangan Sekolah Antara Anak Yang Mengikuti Dan Tidak Mengikuti Les Baca , Tulis, Hitung ( Penelitian pada Siswa TK Swasta di Jakarta ). 7(1), 37-54.

Hanafi. (2017). Konsep Penelitian R \& D Dalam Bidang Pendidikan. Saintifika Islamica: Jurnal Kajian Keislaman, 4(2), 129-150.

Hidayah, N., \& Ulva, R. K. (2017). Pengembangan Media Pembelajaran Berbasis Komik Pada Mata Pelajaran IImu Pengetahuan Sosial Kelas IV MI Nurul Hidayah Roworejo Negerikaton Pesawaran. Terampil Jurnal Pendidikan dan Pembelajaran Dasar, $\quad 4(1)$, 34-46. http://ejournal.radenintan.ac.id/index.php/terampil/article/view/1804

Insight, T. A. (2014). Mobile Device Usage Among Young Kids: A Southeast Asia Study. Asianparent Insights Mobile, November, 1-61. https://s3-ap-southeast1.amazonaws.com/tap-sgmedia/theAsianparent+Insights+Device+Usage+A+Southeast+Asia+Study+Nove mber+2014.pdf

Istiyani, D. (2014). Model Pembelajaran Membaca Menulis Menghitung (Calistung) pada Anak Usia Dini Di Kabupaten Pekalongan. Jurnal Penelitian, 10(1). https://doi.org/10.28918/jupe.v10i1.351

Izzaty, R. E., Ayriza, Y., Setiawati, F. A., \& Amalia, R. N. (2017). Prediktor Prestasi Belajar Siswa Kelas 1 Sekolah Dasar. Jurnal Psikologi, 44(2), 153. https://doi.org/10.22146/jpsi.27454

Juanda, N. I., Waluyanto, H. D., \& Zacky, A. (2015). Perancangan Komik Pembelajaran Bertemakan Fabel Untuk Pembentukan Karakter Pada Anak. Jurnal DKV Adiwarna, 1(6), 11.

Juniarti, P. D., \& Teguh. (2016). Komik why? World customs sebagai media pembelajaran anak usia dini [Universitas Gajah Mada]. http://webcache.googleusercontent.com/search?q=cache:HEnCcmUjD2AJ:etd.rep ository.ugm.ac.id/penelitian/detail/100513+\&cd=1\&hl=id\&ct=clnk\&gl=id 
Khadijah. (2015). Media Pembelajaran. Perdana Pubrishing.

Lasuka, M., Nasirun, M., \& Ardina, M. (2018). Meningkatkan kemampuan pramatematika dengan menggunakan mediabalok cuisenaire pada anak kelompok a2 paud haqiqi kota bengkulu. Jurnal IImiah Potensia, 3, 18-23.

Mariyati, L. I. (2019). Nteligensi dankesiapan anak masuk sekolah dasar. Psyche:jurnal psikolog.

Nirawati, T., \& Yetti, R. (2019). Peningkatan Kemampuan Berhitung Anak Melalui Permainan Meja Putar DiTaman Kanak-Kanak. Indonesian Institute for Counseling, Education and Therapy (IICET), volume 4 , 51-58. file://C:/Users/LENOVO/AppData/Local/Temp/387-961-3-PB.pdf

Nugraheni, N. (2017). Penerapan Media Komik Pada Pembelajaran Matematika Di Sekolah Dasar. Refleksi Edukatika: Jurnal IImiah Kependidikan, 7(2). https://doi.org/10.24176/re.v7i2.1587

Pebriana, P. H. (2017). Analisis Penggunaan Gadget terhadap Kemampuan Interaksi Sosial pada Anak Usia Dini. Jurnal Obsesi : Jurnal Pendidikan Anak Usia Dini, 1(1), 1. https://doi.org/10.31004/obsesi.v1i1.26

Pratiwi, E. (2015). Pembelajaran Calistung Bagi Anak Usia Dini Antara Manfaat Akademik Dan Resiko Menghambat Kecerdasan Mental Anak. Inovasi Pembelajaran untuk Pendidikan Berkemajuan, November, 278-283. http://seminar.umpo.ac.id/index.php/semnasdik2015/article/viewFile/231/231

Priyanto, A. (2015). Pengembangan Kreativitas Pada Anak Usia Dini Melalui Aktivitas Bermain. Jurnal IImiah Guru Caraka Olah Pikir Edukatif, O(2).

Puji Asmaul Chusna. (2017). Pengaruh Media Gadget Pada Perkembangan Karakter Anak. Dinamika Penelitian: Media Komunikasi Sosial Keagamaan, vol 17(no 2), 318.

tulungagung.ac.id/index.php/dinamika/article/viewFile/842/586

http://ejournal.iain-

Purnama, S. (2016). Metode Penelitian Dan Pengembangan (Pengenalan Untuk Mengembangkan Produk Pembelajaran Bahasa Arab). LITERASI (Jurnal IImu Pendidikan), 4(1), 19. https://doi.org/10.21927/literasi.2013.4(1).19-32

Putra, N. (2011). Research and Development: Penelitian dan Pengembangan.

Rahmawati, I. Y. (2017). Media Pembelajaran Komik Sebagai Inovasi Dalam Pembelajaran Keterampilan Membaca Pada Pendidikan Anak Usia Dini ( Paud) Berbasis Nilai Pendidikan Karakter.

Rahmawati, Z. D. (2020). Penggunaan Media Gadget Dalam Aktivitas Belajar Dan Pengaruhnya Terhadap Perilaku Anak Received: Oct 30. 3(1), 97-113.

Remaini. (2019). Peningkatan Kemampuan Mnegenal Konsep Bilangan Melalui Permainan Tabung Pintar di TK Negri Pembina Lubuk Basung. Jurnal Pesona PAUD, 1(9), 1-13. https://doi.org/10.1017/CBO9781107415324.004

Reswita, R., \& Wahyuni, S. (2018). Efektivitas Media Pasir dalam Meningkatkan Kemampuan Konsep Bilangan pada Anak Usia 5-6 Tahun di Tk Aisyiyah Bengkalis. Lectura: Jurnal Pendidikan, 9(1), 43-51. https://doi.org/10.31849/lectura.v9i1.927

Subroto, E. N., Qohar, A., \& Dwiyana. (2020). Efektivitas Pemanfaatan Komik sebagai Media Pembelajaran Matematika. Jurnal Pendidikan: Teori, Penelitian, dan Pengembangan, 5 , 135-141. file://C:/Users/LENOVO/AppData/Local/Temp/13156-19771-1-SM.pdf

Trenggonowati, D. L., \& Kulsum. (2018). Analisis Faktor Optimalisasi Golden Age Anak Usia. Journal Industrial Servicess, 4(1), 48-56. 
Yusuf, M. (2016). Pendidikan Karakter Pada Anak Usia Dini Perspektif Pendidikan Islam. Elementary: Jurnal Ilmiah Pendidikan Dasar, 2 no 1.

Yusuf, M. (2017). the Role of Education Islam for Education Sex and Prevent Sexual Abuse in Children (Case Studies in Ra Metro City Lampung). November 2016.

Zahriani Jf, N., \& Sukiman, S. (2020). Pengembangan Media Flipchart Bertemakan Kelestarian Alam Untuk Mengoptimalkan Kecerdasan Naturalis Anak Di Tkit Zia Salsabila Medan. AWLADY: Jurnal Pendidikan Anak, 6(1), 88. https://doi.org/10.24235/awlady.v6i1.5880 